\section{Federal Rules of Evidence}

Robert L. Heilbronner

Chicago Neuropsychology Group, Chicago, IL, USA

\section{Definition}

The Federal Rules of Evidence (FRE) are rules that control introduction of evidence in civil as well as criminal proceedings in federal courts. Such rules do not apply to suits tried in state courts, though many state rules closely resemble the federal rules. The Federal Rules of Evidence (2006) contain 11 articles including the following: (1) general provisions; (2) judicial note; (3) presumptions in civil actions and proceedings; (4) relevancy and its limits; (5) privileges; (6) witnesses; (7) opinions are expert testimony; (8) hearsay; (9) authentication and identification; (10) contents of writing, recordings, and photographs; and (11) miscellaneous rules. Of critical importance to psychologists and neuropsychologists are the rules contained in section VII of the Federal Rules of Evidence, which relates to "opinions and expert testimony." This article of the document delineates criteria for serving as an expert witness and under what circumstances expert witness testimony is admissible.

\section{Cross-References}

Federal Rules of Civil Procedure 26 \& 35

- Federal Rules of Criminal Procedures

FRE 104, 403, 702, 704

- Hearsay Evidence

\section{References and Readings}

Full text of the "Federal Rules of Evidence (2006)" is available at the following web address: http://www. law.cornell.edu/rules/fre/

Melton, G. B., Petrila, J., Poythress, N. G., \& Slobogin, C. (2007). Psychological evaluations for the courts (3rd ed.). New York: Guilford Press. 